\title{
Targeting the oncogenic protein beta-catenin to enhance chemotherapy outcome against solid human cancers
}

\author{
Maher S Saifo ${ }^{1,2}$, Donald R Rempinski $\mathrm{Jr}^{1}$, Youcef M Rustum', Rami G Azrak
}

\begin{abstract}
Background: Beta-catenin is a multifunctional oncogenic protein that contributes fundamentally to cell development and biology. Elevation in expression and activity of $\beta$-catenin has been implicated in many cancers and associated with poor prognosis. Beta-catenin is degraded in the cytoplasm by glycogen synthase kinase 3 beta (GSK-3ß) through phosphorylation. Cell growth and proliferation is associated with $\beta$-catenin translocation from the cytoplasm into the nucleus.

This laboratory was the first to demonstrate that selenium-containing compounds can enhance the efficacy and cytotoxicity of anticancer drugs in several preclinical xenograft models. These data provided the basis to identify mechanism of selenium action focusing on $\beta$-catenin as a target. This study was designed to: (1) determine whether pharmacological doses of methylseleninic acid (MSeA) have inhibitory effects on the level and the oncogenic activity of $\beta$-catenin, (2) investigate the kinetics and the mechanism of $\beta$-catenin inhibition, and (3) confirm that inhibition of $\beta$-catenin would lead to enhanced cytotoxicity of standard chemotherapeutic drugs.

Results: In six human cancer cell lines, the inhibition of total and nuclear expression of $\beta$-catenin by MSeA was dose and time dependent. The involvement of GSK-3 $\beta$ in the degradation of $\beta$-catenin was cell type dependent

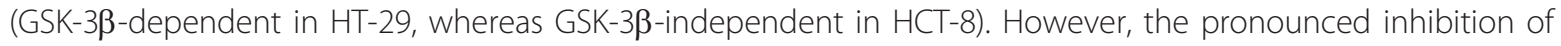
$\beta$-catenin by MSeA was independent of various drug treatments and was not reversed after combination therapy. Knockout of $\beta$-catenin by ShRNA and its inhibition by MSeA yielded similar enhancement of cytotoxicity of anticancer drugs.

Collectively, the generated data demonstrate that $\beta$-catenin is a target of MSeA and its inhibition resulted in enhanced cytotoxicity of chemotherapeutic drugs.

Conclusions: This study demonstrates that $\beta$-catenin, a molecule associated with drug resistance, is a target of selenium and its inhibition is associated with increased multiple drugs cytotoxicity in various human cancers. Further, degradation of $\beta$-catenin by GSK-3 $\beta$ is not a general mechanism but is cell type dependent.
\end{abstract}

\section{Background}

Beta-catenin protein is a vital component of the canonical Wnt/ $\beta$-catenin signaling pathway, which is described as an oncogenic cause in many human cancers [1]. In head and neck squamous cell carcinomas (HNSCC), over expression of the $\mathrm{Wnt} / \beta$-catenin signaling pathway increases cell survival and invasion [2]. The higher $\beta$ catenin expression in HNSCC patients, the more

\footnotetext{
* Correspondence: azrak@roswellpark.org

'Department of Cancer Biology, Roswell Park Cancer Institute, Buffalo, New York, USA

Full list of author information is available at the end of the article
}

advanced stage [3] and poor prognosis are observed [4]. Mutations in the gene that encodes $\beta$-catenin (CTNNB1) [5] and elevated nuclear $\beta$-catenin [6] were implicated in prostate cancers $(\mathrm{CaP})$.

Over $90 \%$ of colorectal cancers (CRC) demonstrate a deregulated Wnt/ $\beta$-catenin signaling pathway [7]. Published studies suggest that unregulated $\beta$-catenin, overlapping with adenomatous polyposis coli (APC) mutation, is associated with the initiation of CRC [8-10]. Beta-catenin is expressed in the cytoplasm and the nucleus. The cytoplasm $\beta$-catenin, as a component of adherens junctions (AJs) [11], is an essential element of

\section{Biomed Central}


cell-to-cell adhesion and stability. The level of cytoplasm $\beta$-catenin is controlled by the activity of a destruction complex that consists of axin, glycogen synthase kinase $3 \beta$ (GSK-3 $\beta$ ) and APC [12-15]. In the absence of Wnt signaling, the complex is assembled and GSK-3 $\beta$ phosphorylates and consequently degrades cytoplasm $\beta$-catenin $[14,15]$. However, GSK-3 $\beta$ is inactivated in cancer cells by phosphorylation at serine 9 , a similar mechanism of GSK-3 $\beta$ inhibition by lithium $[16,17]$. In the presence of Wnt signaling, $\beta$-catenin destruction complex is disassembled by removing axin $[18,19]$ resulting in $\beta$-catenin accumulation in the cytoplasm. The accumulated cytoplasm $\beta$-catenin hence enters the nucleus to initiate its oncogenic function. The nuclear $\beta$-catenin has an important function in many human malignancies [1] by stimulating cell growth and proliferation. The nuclear $\beta$-catenin affects TCF/LEF family transcription factors $[20,21]$ and consequently activates oncogenes such as cyclin D1 [22,23], Myc [24] and many other downstream targets. The nuclear accumulation of $\beta$-catenin is a critical step in the activation process of the canonical Wnt signaling pathway and is associated with poor prognosis in cancer patients [25].

In addition to its role in cell growth and adhesion, activated canonical $\mathrm{Wnt} / \beta$-catenin signaling pathway is linked to cancer stem cells $[26,27]$ that contribute to tumor bulk, recurrence and resistance to chemotherapy. Accordingly, $\beta$-catenin inhibitors in combination with standard systemic therapies hold great promise to improve treatment's efficacy and outcome.

The response rates of combination regimen of irinotecan and 5-fluorouracil/leucovorin (5-FU/LV) is 39\% in metastatic CRC [28]. Treatment with oxaliplatin and 5$\mathrm{FU} / \mathrm{LV}$ has improved the response rate to $50.7 \%$ in CRC [29]. Treatment with docetaxel and prednisone against metastatic $\mathrm{CaP}$ resulted in a median survival of 19.2 months [30]. Docetaxel in combination with cisplatin and 5-FU against inoperable advanced HNSCC resulted in a median progression free survival of 11 months [31]. Although the relative survival in advanced solid tumors is improved by using systemic therapy, the current chemotherapy cure rates are limited. Thus, the development of new regimens is greatly needed to achieve a better clinical outcome.

In our preclinical models, selenium-containing compounds enhanced the efficacy of multiple chemotherapeutic agents (CPT-11 or docetaxel) against various types of cancers (colorectal, head and neck and prostate) $[32,33]$. In mice bearing human colorectal cancer xenografts (HCT-8), combination treatment of MSC and irinotecan resulted in complete tumor regression $(100 \%$ CR) that was not observed with each drug alone $(30 \%$ CR) [32]. Sequential combination of MSeA and docetaxel resulted in synergy enhancing docetaxel-induced cell death in CaP [33]. Multiple mechanisms of the synergy between selenium and other chemotherapeutic agents are proposed. Selenium (Se) is an essential element that possesses antioxidant properties in a form of selenoproteins protecting cells from harmful free radicals [34-36]. The effect of selenium on $\beta$-catenin has yet to be investigated.

This study is designed mainly to determine if $\beta$-catenin is a target of MSeA in CRC, HNSCC and CaP cancers; and to evaluate the role of GSK-3 $\beta$ in the degradation of $\beta$-catenin and if such an effect is associated with enhanced cytotoxicity of anticancer drugs.

\section{Results}

Inhibition of $\beta$-catenin by MSeA is concentration, time and tumor type dependent

To evaluate the effect of MSeA on the expression of $\beta$-catenin, various tumor cell types were treated with multiple time and doses of MSeA. In all treated cells, MSeA decreased the expression of $\beta$-catenin in dose and time dependent manners (Figure 1). The data in Figure 1 indicate that the down regulation of $\beta$-catenin is MSeA concentration dependent. In CRC cells (HCT-8 and HT-29), $24 \mathrm{~h}$ treatment with $5 \mu \mathrm{M}$ resulted in completely depletion of $\beta$-catenin. In contrast, in HNSCC cells ( $\mathrm{FaDu}$ and $\mathrm{A} 253$ ), the decrease in $\beta$-catenin levels in $\mathrm{FaDu}$ cells was achieved with lower concentrations of MSeA $(0.5 \mu \mathrm{M})$ than in A253 $(5 \mu \mathrm{M})$ (Figure 1A). In the androgen-independent $\mathrm{CaP}$ cells (PC3 and $\mathrm{C} 42$ ), inhibition of $\beta$-catenin by MSeA required a high concentration $(5 \mu \mathrm{M})$ (Figure 1A). The kinetics of $\beta$-catenin inhibition by MSeA appears to be tumor type dependent, early in HCT-8, C42, HT-29 and PC3, and late event in FaDu and A253 (Figure 1B).

\section{MSeA inhibits $\beta$-catenin nuclear expression}

To determine whether MSeA down regulates the activity of $\beta$-catenin, nuclear and cytoplasmic extracts of colorectal cancer cells were tested for the level of $\beta$-catenin before and after MSeA treatment. The data in Figure 2A indicate that $\beta$-catenin is predominantly expressed in the nucleus of untreated CRC cells (HCT-8 and HT-29) indicating activation of $\beta$-catenin. Treatments with MSeA resulted in inhibition of nuclear expression of $\beta$-catenin (Figure 2B). These data suggest that MSeA down regulates $\beta$-catenin activity through inhibiting its nuclear expression.

\section{Inhibition of $\beta$-catenin is due to enhanced degradation}

To determine whether the observed down regulation of $\beta$-catenin by MSeA results from inhibition of its synthesis or from increased degradation, cells were treated with MSeA and cycloheximide (an inhibitor of de novo protein synthesis [37]) alone and in combination. 


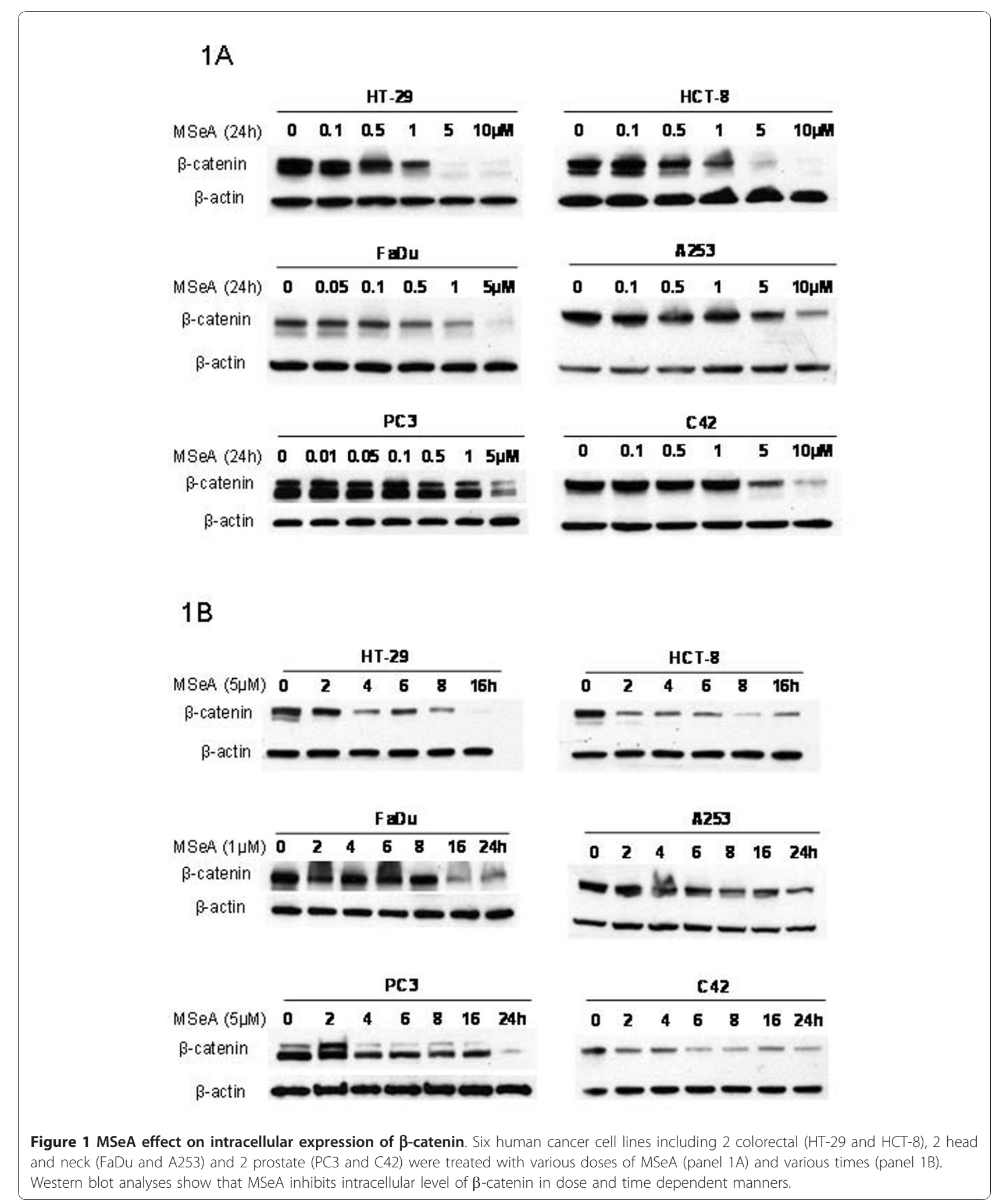




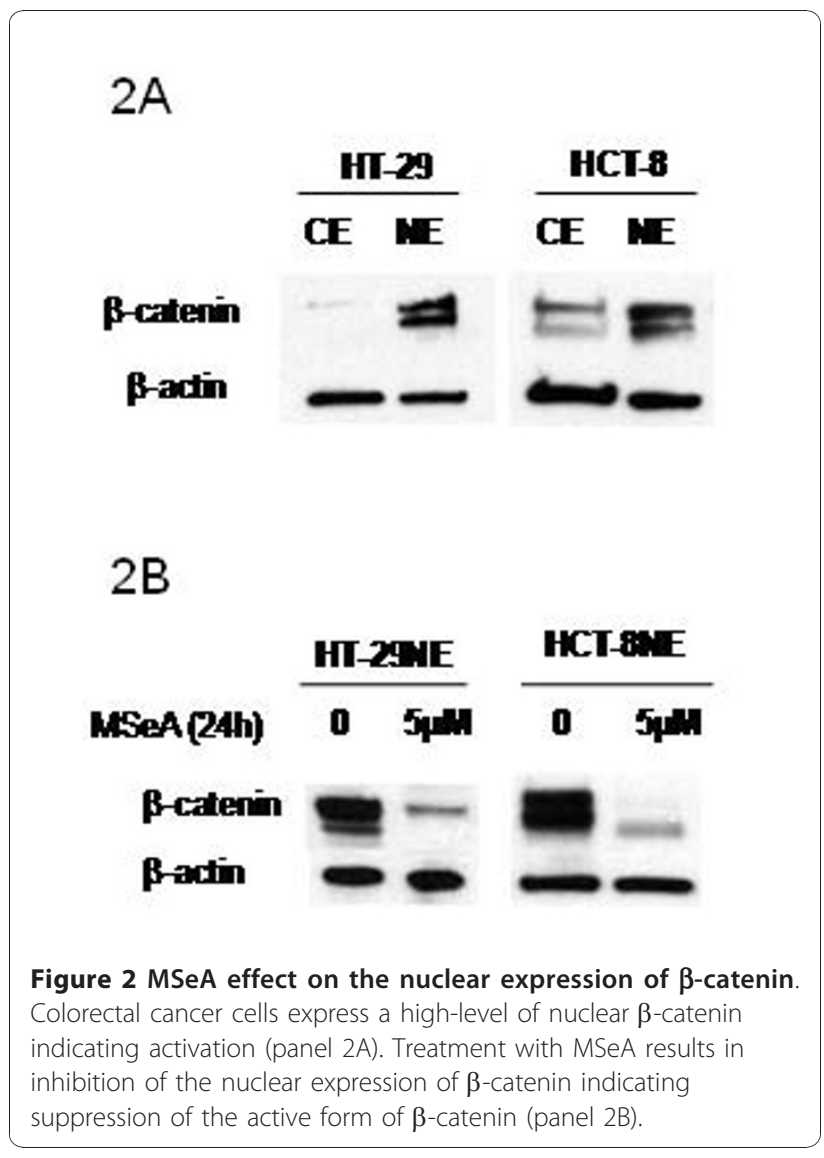

Treatments for up to 30 minutes did not affect the expression level of $\beta$-catenin (Figure 3A). However, $\beta$-catenin is down regulated after $24 \mathrm{~h}$ treatment with MSeA alone and in combination with cycloheximide (Figure 3B). These data suggest that the inhibition of $\beta$-catenin by MSeA is the result of increased degradation.

The role of GSK-3 $\beta$ in $\beta$-catenin degradation is cell type dependent

To determine the mechanism of $\beta$-catenin degradation by MSeA, the role of GSK-3 $\beta$ was evaluated in HT-29 and HCT-8 (Figure 4). Treatments with MSeA had no significant effect on the level of total GSK-3 $\beta$ (in HT-29 or HCT-8) and on the level of phosphorylated GSK-3 $\beta$ in HCT-8. In contrast, phosphorylated GSK-3 $\beta$ was significantly decreased in HT-29 (Figure 4A).

To evaluate further the role of GSK-3 $\beta$, cells were treated with lithium chloride ( $\mathrm{LiCl}$ ) alone (GSK-3 $\beta$ inhibitor [38]) and in combination with MSeA. Treatment with $\mathrm{LiCl}$ increased the level of phosphorylated GSK-3 $\beta$ in both cell lines indicating inhibition of GSK-3ß (Figure 4B). Combination of MSeA with various doses of $\mathrm{LiCl}$ resulted in reversing the down regulation of $\beta$-catenin in HT-29 cells but not HCT-8 by MSeA (Figure 4B). Data in Figure 4 demonstrated that the inhibition of
$3 \mathrm{~A}$
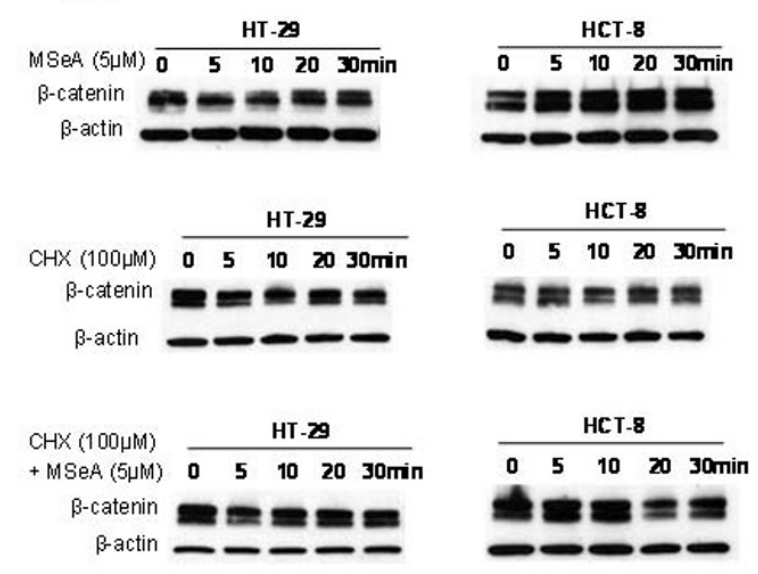

3B
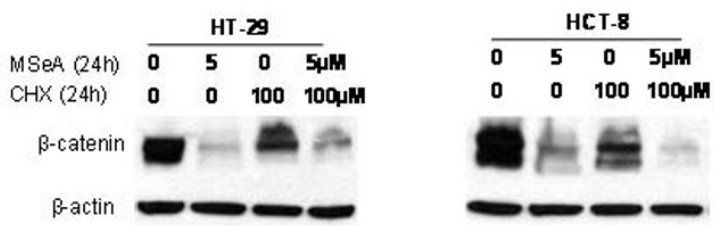

Figure $3 \mathrm{MSeA}$ inhibition of $\beta$-catenin is due to degradation Colorectal cancer cells were treated with a protein synthesis inhibitor, cycloheximide (CHX) and MSeA alone or in combination for various times up to 30 minutes (panel $3 \mathrm{~A}$ ) and for $24 \mathrm{~h}$ (panel $3 B$ ). No early changes in the $\beta$-catenin level were observed (panel $3 \mathrm{~A})$. However, $24 \mathrm{~h}$ combination treatment with $\mathrm{CHX} / \mathrm{MSeA}$ resulted in same inhibition after MSeA alone (panel 3B).

$\beta$-catenin by MSeA is GSK- $3 \beta$ phosphorylation dependent in HT-29 but independent in HCT-8.

The effect of MSeA in combination therapy on the level and activity of $\beta$-catenin

To determine whether MSeA in combination with a chemotherapeutic agent would affect $\beta$-catenin expression and activity, cells were treated with MSeA \pm chemotherapeutic agent and analyzed for total and nuclear $\beta$-catenin expression. The data in Figure 5A indicate that MSeA inhibited $\beta$-catenin expression in all cell lines but neither 7-Ethyl-10-Hydroxycamptothecin (SN-38, the active metabolite of irinotecan) nor docetaxel alone had an effect on the $\beta$-catenin levels. Adding SN-38 or docetaxel to MSeA did not interfere with selenium inhibition of $\beta$-catenin. The combination of MSeA/SN-38 resulted in even more observed inhibition of total $\beta$-catenin when compared with MSeA alone in HT-29, HCT-8 and FaDu cells. In $\mathrm{CaP}$ cells, MSeA alone and in combination with docetaxel have similar inhibitory effect on the expression of 


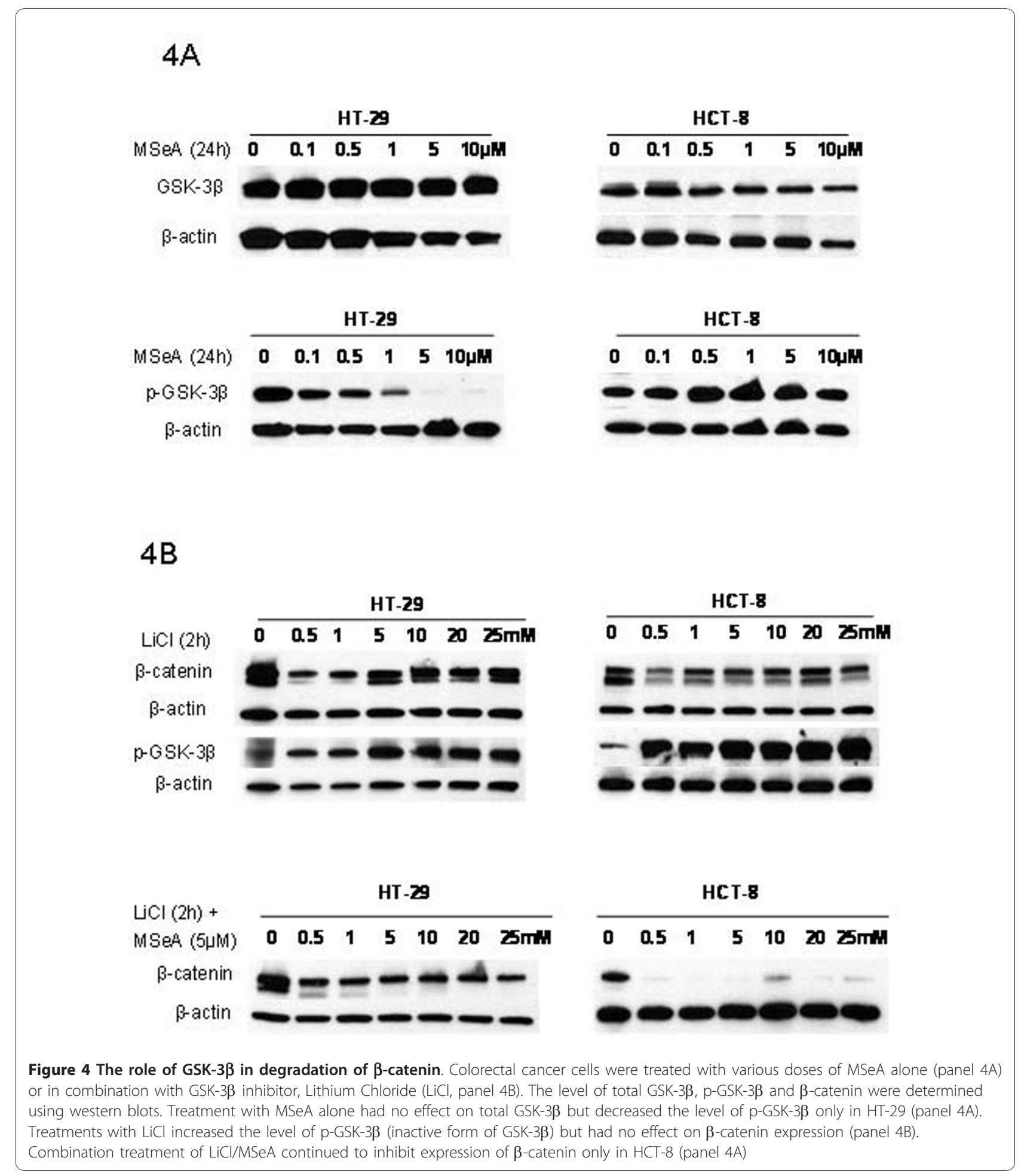

$\beta$-catenin (Figure $5 \mathrm{~A}$ ). To determine whether the inhibition of $\beta$-catenin by MSeA in combination with $\mathrm{SN}-38$ is due to inhibition of the nuclear expression, nuclear extracts of CRC cells were treated with MSeA alone and in combination with $\mathrm{SN}-38$ and evaluated for the level of $\beta$-catenin. The combination treatment of MSeA/SN-38 resulted in down regulation of the nuclear expression of $\beta$-catenin in HT-29 and HCT-8 cells (Figure 5B). These results indicate that the activity of $\beta$-catenin is decreased after the combination therapy. 


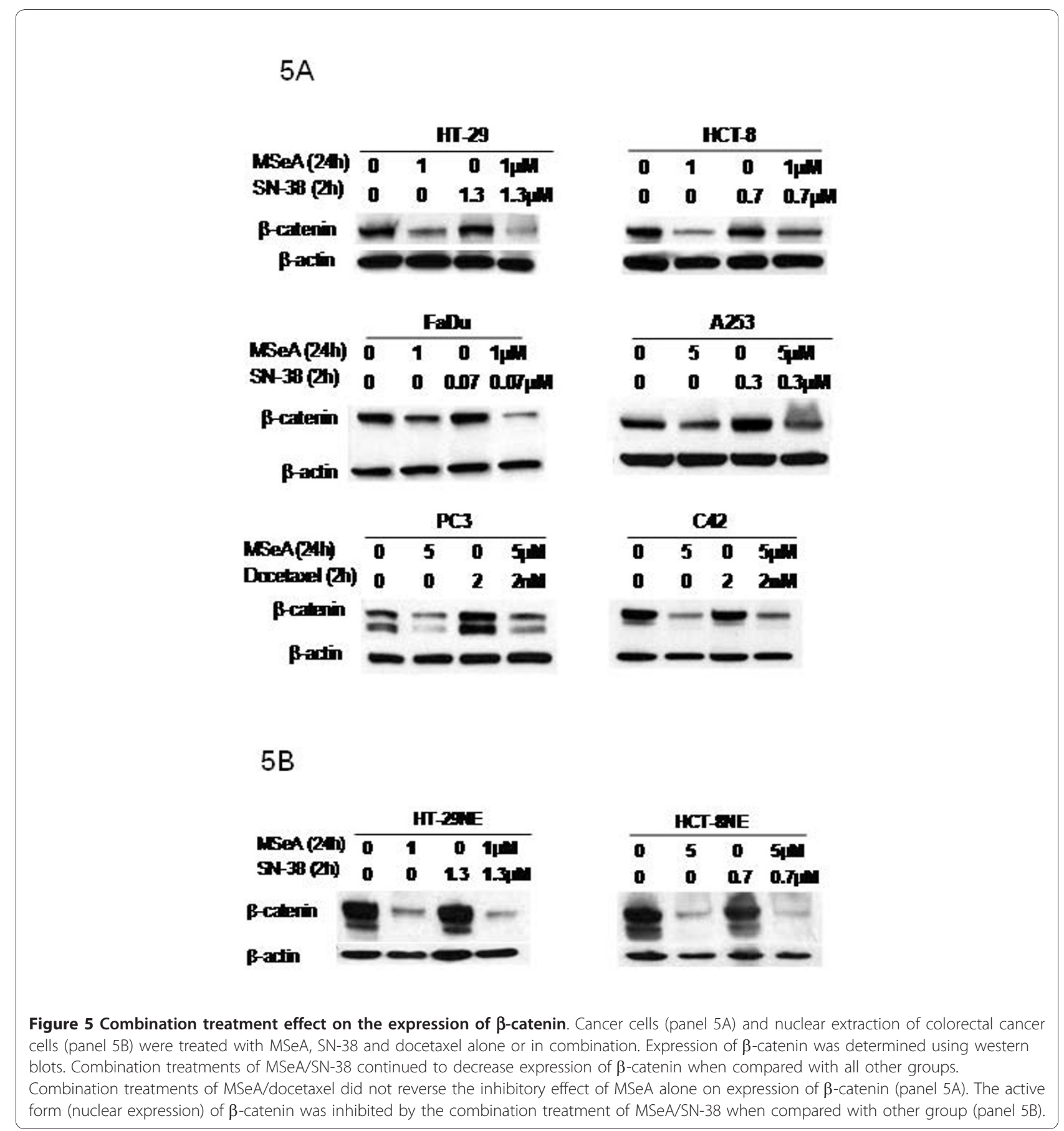

The inhibition of $\beta$-catenin expression by ShRNA or MSeA is associated with enhancement of drug-induced growth inhibition of tumor cell

To determine whether inhibition of $\beta$-catenin can be correlated with enhanced efficacy of chemotherapy, $\beta$-catenin in tumor cells was knockdown by specific ShRNA. Two $\beta$-catenin ShRNA tranfectant clones (HCT-8RH7 and HCT-8RF4) that demonstrated inhibition of $\beta$-catenin expression when compared with scrambled control (HCT-8SC) and wild type (HCT$8 \mathrm{WT}$ ) were selected for further testing (Figure 6A).

To evaluate the effect of silencing $\beta$-catenin on cell growth, HCT-8WT, HCT-8SC and HCT-8R (HCT8RH7 and HCT-8RF4) transfectants were treated with various classes of chemotherapeutic agents. Treatments with $0.5 \mu \mathrm{M}$ of SN-38 were more effective $(\mathrm{p}<0.05)$ against HCT-8R ( $\sim 50 \%$ cell growth inhibition) when compared with all other groups $(15 \%$ cell growth 


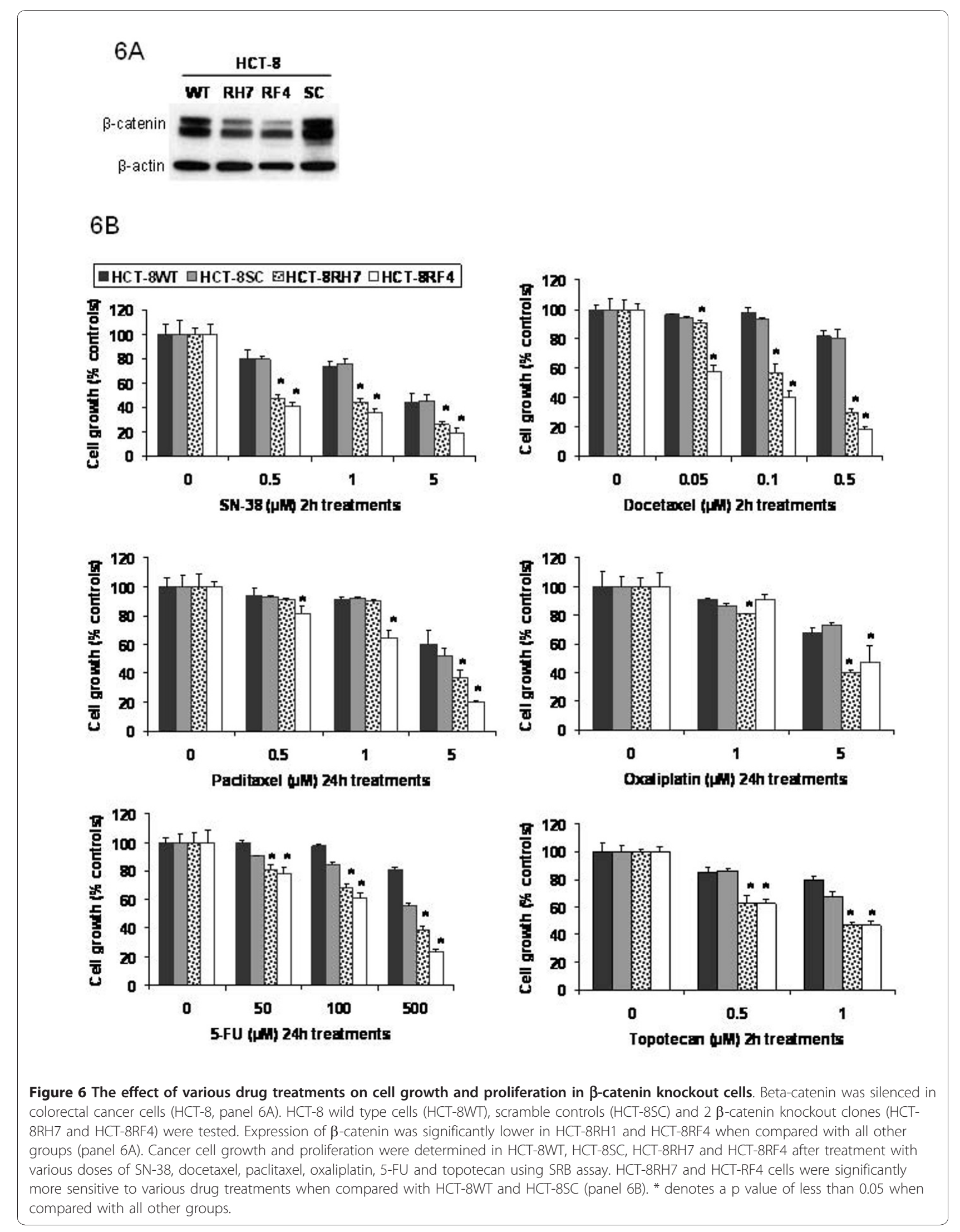


inhibition in HCT-8SC or HCT-8WT, Figure 6B). Other doses of SN-38 resulted in similar patterns of inhibition of cell growth (Figure 6B). In similar fashion, treatments with various doses of docetaxel, paclitaxel, oxaliplatin, 5FU and topotecan significantly enhanced efficacy against cell growth of HCT-8RH7 and HCT-8RF4 when compared with all other groups of HCT-8SC or HCT-8WT (Figure 6B).

To confirm further that inhibition of $\beta$-catenin is associated with enhanced cytotoxicity of anticancer drugs, tumor cells were treated with MSeA alone and in combination with SN-38 and the results were correlated with the levels of $\beta$-catenin (table 1 ). The data in table 1 demonstrated a relationship between enhanced cytotoxicity of SN-38 and inhibition of $\beta$-catenin by MSeA or ShRNA. Thus, these data support the initial hypothesis that inhibition of $\beta$-catenin by MSeA is a critical determinant of drug response.

\section{Discussion}

Beta-catenin oncogonic protein is widely expressed in many human malignancies [1] including HNSCC [2-4], $\mathrm{CaP}[5,6]$ and CRC [8-10]. Beta-catenin is involved in cell growth [22-24], adhesion [11] and stemness [26,27]. Beta-catenin is found in multiple cellular locations including intracellular membrane, cytoplasm and nucleus. The nuclear accumulation of $\beta$-catenin indicates the activation of its oncogenic form that stimulates transcription factors and genes [22-24] leading to enhanced tumor cell growth and poor prognosis [25]. The hypothesis of this study is that $\beta$-catenin is a target of MSeA and its inhibition would translate into enhanced drug effect. Our results (Figure 1) established that MSeA is a potent inhibitor of $\beta$-catenin in various cancer types. This broad inhibitory effect of MSeA on the expression of $\beta$-catenin is pivotal for explaining the established synergy between selenium and various chemotherapeutic agents against multiple cancers.

The data in Figure 2 demonstrate that the inhibition of $\beta$-catenin level after MSeA is due to the inhibition of the active form of $\beta$-catenin in the nucleus. Thus, these

\begin{tabular}{|c|c|c|}
\hline HCT-8 cell line & $\%$ cell growth inhibition & Beta-catenin expression \\
\hline Control & $0 \%$ & $++++/$ strong \\
\hline MSeA (1 $\mu \mathrm{M})$ & $\sim 50 \%$ & ++/weak \\
\hline SN-38(0.7 $\mu \mathrm{M})$ & $\sim 20 \%$ & $++++/$ strong \\
\hline MSeA+SN-38 & $>95 \%$ & +/very weak \\
\hline ShRNA & $0 \%$ & ++/weak \\
\hline ShRNA+SN38 & $\sim 70 \%$ & +/very weak \\
\hline
\end{tabular}

data indicate that pharmacologic doses of MSeA offer effective inhibition of $\beta$-catenin activation.

Recent findings by Zhang et al demonstrate that selenium effect against esophageal squamous cell carcinoma is correlated with its inhibition on $\beta$-catenin/TCF pathway [39]. Our results confirm this finding in various human cancers and prove that the decreased level of $\beta$-catenin is associated with enhanced efficacy of various classes of chemotherapy. Thus, indicating the importance of $\beta$-catenin inhibition in drug response.

To determine whether the inhibition of $\beta$-catenin is due to a decrease in synthesis or an increase in degradation, de novo protein synthesis was inhibited using $\mathrm{CHX}$ in the presence and absences of MSeA. The data in Figure 3 indicate that MSeA inhibition of $\beta$-catenin is due to increase in degradation but not decrease in synthesis in both CRC cells (HT-29 and HCT-8). Many studies have showed that cytoplasm $\beta$-catenin is degraded by an axin/GSK-3 $\beta / A P C$ complex [12-14] and the degradation is a GSK-3 $\beta$ phosphorylation dependent process $[14,15]$. The degradation of the cytoplasm $\beta$-catenin prevents its accumulation and translocation into the nucleus. Data in Figure 4 demonstrated that the inhibition of $\beta$-catenin by MSeA is GSK-3 $\beta$ dependent phosphorylation in HT-29 but independent in HCT-8. The GSK-3 $\beta$ independent degradation of $\beta$-catenin is a novel finding in HCT-8 cells and indicates that the MSeA effect involves other signaling pathways than $\mathrm{Wnt} / \beta$-catenin, which will be investigated in future studies.

In preclinical models, sequential combination treatment of selenium compounds (MSC, SLM or MSeA) and various chemotherapeutic agents (SN-38 or docetaxel) were proven synergistic against various cancers including HNSCC, CRC and CaP [32,33]. Studies were carried out to determine whether the combination treatment of MSeA and chemotherapeutic agents affect $\beta$-catenin level in those cell lines. Our results in Figure 5 showed that treatment with MSeA in combination with SN-38 or docetaxel down regulated the total and the nuclear $\beta$-catenin. These results confirm that the chemotherapeutic agent did not interfere with selenium inhibition of the level and activity of $\beta$-catenin. However, neither $\mathrm{SN}-38$ nor docetaxel alone affect the expression level of $\beta$-catenin (Figure 5).

To determine that inhibition of $\beta$-catenin by MSeA will translate into enhanced drug-cytotoxicity, cells knocked down $\beta$-catenin by ShRNA were more sensitive to growth inhibition by SN-38 than wild type. Collectively, this study indicates that the decreased level of $\beta$-catenin is associated with enhancement of drug induced inhibition of cell growth. (table 1).

Further, the data in Figure 6 indicate that silencing $\beta$-catenin increases the cytotoxicity of various chemotherapeutic agents. The efficacy of SN-38, docetaxel, paclitaxel, 
oxaliplatin, 5-FU and topotecan was significantly increased in HCT-8R when compared with control groups (Figure 6B).

\section{Conclusions}

These results support the hypothesis that $\beta$-catenin is a target of MSeA and its inhibition results in enhanced drug-cytotoxicity in multiple cancers. Degradation of $\beta$-catenin by GSK-3 $\beta$ is not a general mechanism but it is cell type dependent.

Although Selenium is a multi-target agent $[32,33,40]$, inhibition of $\beta$-catenin is a critical determinant of drug response. These preclinical results provided the rationale for validation of this new and innovative approach in a clinical setting.

\section{Materials and methods Cell lines and drugs}

Human cancer cell lines of colorectal (HCT-8 and HT29), head and neck (FaDu and A253) and prostate (PC3 and C42) were purchased from American type cell culture (ATCC, Manassas, VA) and maintained in RPMI 1640 with $10 \%$ fetal bovine serum (FBS). The cell lines were tested regularly using Stratogene's mycoplasma plus PCR Primer set (La Jolla, CA) and they were free from Mycoplasma. SN-38, docetaxel, 5-FU, paclitaxel, oxaliplatin, lithium chloride $(\mathrm{LiCl})$ and cycloheximide (CHX) were purchased from Sigma Aldrich (St. Louis, $\mathrm{MO})$. MSeA $\left(\mathrm{CH}_{3} \mathrm{SeO}_{2} \mathrm{H}\right)$ was purchased from PharmaSe Inc. (Lubbock, TX). Toptecan was obtained from GlaxoSmithKline (Durham, NC). Puromycin dihydrochloride, plasmid transfection medium and transfection reagents were purchased from Santa Cruz biotechnology Inc. (Santa Cruz, CA).

\section{Schedules and drug doses}

Cells were treated with various doses of MSeA $(0.05$, $0.1,0.5,1,5$ and $10 \mu \mathrm{M})$ for various times $(2,4,6,8,16$ and $24 \mathrm{~h}$ ). MSeA and SN-38 or docetaxel were given alone or in sequential combination. In sequential combination, $2 \mathrm{~h}$ treatments with SN-38 (0.7, 1.3, 0.07 and 0.3 $\mu \mathrm{M}$ against HCT-8, HT-29, FaDu and A253 respectively) or docetaxel (2 $\mathrm{nM}$ against PC3 and C42) started $22 \mathrm{~h}$ after treatment with MSeA (1 or $5 \mu \mathrm{M})$. HCT-8 parental and $\beta$-catenin knockout cells were treated with SN-38 (2 h), docetaxel (2 h), paclitaxel ( $24 \mathrm{~h})$, oxaliplatin (24 h), 5-FU (24 h) and topotecan (2 h) using various doses. The doses were for SN-38 $(0.5,1$ and $5 \mu \mathrm{M})$, for docetaxel $(0.05,0.1$ and $0.5 \mu \mathrm{M})$, for paclitaxel $(0.5,1$ and $5 \mu \mathrm{M}$ ), for oxaliplatin ( 1 and $5 \mu \mathrm{M})$, for 5 -FU ( 50 , 100 and $500 \mu \mathrm{M})$ and for topotecan $(0.5$ and $1 \mu \mathrm{M})$. $\mathrm{LiCl}$ was applied for $24 \mathrm{~h}$ in multiple doses $(0.5,1,5$, 10,20 and $25 \mathrm{mM}$ ) alone or in combination with MSeA $(5 \mu \mathrm{M})$.
Cycloheximide (CHX) was applied for 5, 10, 20, 30 minutes and 24 hours at a nontoxic concentration of $100 \mu \mathrm{M}$ alone or in combination with MSeA $(5 \mu \mathrm{M})$. Puromycin dihydrochloride was used at concentration of $20 \mu \mathrm{M}$ for clones' selection.

\section{Preparation of cytoplasm and nuclear extract}

Cytoplasm and nuclear extracts were prepared as previously described [41]. Briefly, to obtain cytoplasm extract, untreated and treated HCT-8 cells were harvested and suspended in lysis buffer $(0.08 \mathrm{M} \mathrm{KCl}, 35$ mM HEPES, $\mathrm{pH}$ 7.4, $5 \mathrm{mM}$ potassium phosphate, $\mathrm{pH}$ 7.4, $5 \mathrm{mM} \mathrm{MgCl}_{2}, 25 \mathrm{mM} \mathrm{CaCl}_{2}, 0.15 \mathrm{M}$ sucrose, $2 \mathrm{mM}$ PMSF, $8 \mathrm{mM}$ dithiothreitol). After overnight storage at $-80^{\circ} \mathrm{C}$, cells were passed through a 28 -gauge needle, centrifuged and the supernatant collected to represent the cytoplasm extract. The remaining pellet was re-suspended in lysis buffer, sonicated, centrifuged and the supernatant collected to represent the nuclear extract.

\section{Silencing the expression of $\beta$-catenin}

HCT- 8 cells were utilized to generate a stable transfection using small hairpin $\beta$-catenin RNA ( $\beta$-catenin ShRNA) purchased from Santa Cruz Biotechnology Inc. (Santa Cruz, CA). Transfection was carried out following the manufacture's instructions. Briefly, HCT- 8 cells were plated $5 \times 10^{5}$ cells/well (6-well plate) one day before the transfection. A well with $70-80 \%$ cells confluence was transfected with control shRNA Plasmid-A (a negative control) that encodes a scrambled shRNA sequence that does not inhibit $\beta$-catenin to generate HCT-8 scrambled control (HCT-8SC). Another well with the same cells confluence, was transfected with $\beta$ catenin shRNA plasmid DNA, a $\beta$-catenin-specific lentiviral vector plasmid to knock down expression and generate HCT-8 recombinant clones (HCT-8R). Clones of stable transfectants were selected using $20 \mu \mathrm{M}$ of puromycin dihydrochloride. After selection, 10 individual clones were evaluated using western blots and the 2 clones (HCT-8RH7 and HCT-8RF4) that demonstrated the most effect of survivin suppression were selected for further studies.

\section{Western blots analyses}

Western blots were performed as described previously [33] to determine the effects on the intracellular protein levels. Briefly, untreated and treated cells were collected and digested using RIPA buffer $(1 \mathrm{M}$ Tris, $1 \mathrm{M} \mathrm{NaCl}$, Triton X-100 and distilled water) with fresh protease inhibitor cocktail. Protein level was measured using BioRad DC protein assay and a synergy HT spectrophotometer (BioTek Instruments, Winooski, VT). Equal amount of protein $(50 \mu \mathrm{g})$ was loaded on $4-20 \%$ SDSPAGE. After transfer, nitrocellulose membrane was 
rinsed with PBS-T, blocked with 5\% milk and hybridized with the selected antibody. The following primary anti-

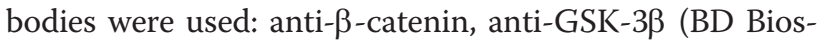
ciences, San Jose, CA) and anti-p-GSK-3 $\beta$ (cell signaling technology, Danvers, MA). The following secondary antibodies were used: goat anti-mouse IgG and goat anti-rabbit IgG (Santa Cruz Biotechnology, Santa Cruz, CA). After incubation with the primary and secondary antibodies, membrane was rinsed and incubated with chemilluminescence or enhanced chemilluminescence and developed using Kodak X-OMAT 2000A (First Source Inc., Rochester, NY). Anti- $\beta$-actin (Sigma Aldrich, St. Louis, MO) was used as loading controls.

\section{Cell growth assay}

Cell growth was evaluated using sulforhodlamine B (SRB) assay as previously described and performed [33]. Briefly, after drug treatment, HCT-8WT, HCT-8SC and HCT-8RH7 and HCT-8RF4 cells were incubated in a drug-free medium for 5 days, fixed, washed and stained with SRB dye. The optical density of bound dye was measured at $570 \mathrm{~nm}$ using synergy HT multi-mode microplate reader (BioTek Instruments, Winooski, VT).

\section{Statistical analyses}

Each experiment has been repeated at least 3 times. Values were presented as the mean plus or minus standard deviation. Statistical analyses were performed comparing all treatments groups using unpaired $t$-student test. Significant difference between groups was noted when the $\mathrm{p}$ value was less than 0.05 .

\section{Acknowledgements \\ This research was supported, in part, by a Research Grant IRG-02-197-06 (RGA) form the American Cancer Society; and, in part, by the $\mathrm{NCl}$ Cancer Center Support Grant to the Roswell Park Cancer Institute CA016056.}

\section{Author details}

${ }^{1}$ Department of Cancer Biology, Roswell Park Cancer Institute, Buffalo, New York, USA. '2Department of Oncology, Albairouni University Hospital, Damascus University, Damascus Syria.

\section{Authors' contributions}

MSS performed and designed experiments, prepared and wrote the manuscript. DRR performed cytotoxicity experiments. YMR participated in study design, data interpretation and preparation of the manuscript. RGA designed the research strategy, supervised the project, assisted in data generation, results interpretation and correction of the manuscript. All authors read and approved the final manuscript.

\section{Competing interests}

The authors declare that they have no competing interests.

Received: 3 August 2010 Accepted: 2 December 2010 Published: 2 December 2010

\section{References}

1. Giles $\mathrm{RH}$, van Es $\mathrm{JH}$, Clevers $\mathrm{H}$ : Caught up in a Wnt storm: Wnt signaling in cancer. Biochim Biophys Acta 2003, 1653:1-24.
2. Yang F, Zeng Q, Yu G, Li S, Wang CY: Wnt/beta-catenin signaling inhibits death receptor-mediated apoptosis and promotes invasive growth of HNSCC. Cell Signal 2006, 18:679-687.

3. Goto M, Mitra RS, Liu M, Lee J, Henson BS, Carey T, Bradford C, Prince M, Wang CY, Fearon ER, D'Silva NJ: Rap1 stabilizes beta-catenin and enhances beta-catenin-dependent transcription and invasion in squamous cell carcinoma of the head and neck. Clin Cancer Res 2010, 16:65-76.

4. Tsai YP, Yang MH, Huang CH, Chang SY, Chen PM, Liu CJ, Teng SC, Wu KJ: Interaction between HSP60 and beta-catenin promotes metastasis. Carcinogenesis 2009, 30:1049-1057.

5. Gerstein AV, Almeida TA, Zhao G, Chess E, Shih le M, Buhler K, Pienta K, Rubin MA, Vessella R, Papadopoulos N: APC/CTNNB1 (beta-catenin) pathway alterations in human prostate cancers. Genes Chromosomes Cancer 2002, 34:9-16.

6. Chesire DR, Ewing CM, Sauvageot J, Bova GS, Isaacs WB: Detection and analysis of beta-catenin mutations in prostate cancer. Prostate 2000, 45:323-334.

7. Fevr T, Robine S, Louvard D, Huelsken J: Wnt/beta-catenin is essential for intestinal homeostasis and maintenance of intestinal stem cells. Mol Cell Biol 2007, 27:7551-7559.

8. Morin PJ, Sparks AB, Korinek V, Barker N, Clevers H, Vogelstein B, Kinzler KW: Activation of beta-catenin-Tcf signaling in colon cancer by mutations in beta-catenin or APC. Science 1997, 275:1787-1790.

9. Wagenaar RA, Crawford HC, Matrisian LM: Stabilized beta-catenin immortalizes colonic epithelial cells. Cancer Res 2001, 61:2097-2104.

10. Sparks AB, Morin PJ, Vogelstein B, Kinzler KW: Mutational analysis of the APC/beta-catenin/Tcf pathway in colorectal cancer. Cancer Res 1998, 58:1130-1134.

11. Conacci-Sorrell M, Zhurinsky J, Ben-Ze'ev A: The cadherin-catenin adhesion system in signaling and cancer. J Clin Invest 2002, 109:987-991.

12. Behrens J, Jerchow BA, Wurtele M, Grimm J, Asbrand C, Wirtz R, Kuhl M Wedlich D, Birchmeier W: Functional interaction of an axin homolog, conductin, with beta-catenin, APC, and GSK3beta. Science 1998, 280:596-599.

13. Hart MJ, de los Santos R, Albert IN, Rubinfeld B, Polakis P: Downregulation of beta-catenin by human Axin and its association with the APC tumor suppressor, beta-catenin and GSK3 beta. Curr Biol 1998, 8:573-581.

14. Ikeda S, Kishida S, Yamamoto H, Murai H, Koyama S, Kikuchi A: Axin, a negative regulator of the Wnt signaling pathway, forms a complex with GSK-3beta and beta-catenin and promotes GSK-3beta-dependent phosphorylation of beta-catenin. Embo J 1998, 17:1371-1384.

15. Yost C, Torres M, Miller JR, Huang E, Kimelman D, Moon RT: The axisinducing activity, stability, and subcellular distribution of beta-catenin is regulated in Xenopus embryos by glycogen synthase kinase 3. Genes Dev 1996, 10:1443-1454.

16. De Sarno P, Li X, Jope RS: Regulation of Akt and glycogen synthase kinase-3 beta phosphorylation by sodium valproate and lithium. Neuropharmacology 2002, 43:1158-1164.

17. Beurel E, Kornprobst M, Blivet-Van Eggelpoel MJ, Ruiz-Ruiz C, Cadoret A, Capeau J, Desbois-Mouthon C: GSK-3beta inhibition by lithium confers resistance to chemotherapy-induced apoptosis through the repression of CD95 (Fas/APO-1) expression. Exp Cell Res 2004, 300:354-364.

18. Cliffe A, Hamada F, Bienz M: A role of Dishevelled in relocating Axin to the plasma membrane during wingless signaling. Curr Biol 2003, 13:960-966.

19. Nusse R: Cell biology: relays at the membrane. Nature 2005, 438:747-749.

20. Huber O, Korn R, McLaughlin J, Ohsugi M, Herrmann BG, Kemler R: Nuclear localization of beta-catenin by interaction with transcription factor LEF1. Mech Dev 1996, 59:3-10.

21. Molenaar M, van de Wetering M, Oosterwegel M, Peterson-Maduro J, Godsave S, Korinek V, Roose J, Destree O, Clevers H: XTcf-3 transcription factor mediates beta-catenin-induced axis formation in Xenopus embryos. Cell 1996, 86:391-399.

22. Shtutman M, Zhurinsky J, Simcha I, Albanese C, D'Amico M, Pestell R, BenZe'ev A: The cyclin D1 gene is a target of the beta-catenin/LEF-1 pathway. Proc Natl Acad Sci USA 1999, 96:5522-5527.

23. Tetsu O, McCormick F: Beta-catenin regulates expression of cyclin D1 in colon carcinoma cells. Nature 1999, 398:422-426. 
24. He TC, Sparks AB, Rago C, Hermeking H, Zawel L, da Costa LT, Morin PJ, Vogelstein B, Kinzler KW: Identification of c-MYC as a target of the APC pathway. Science 1998, 281:1509-1512.

25. Park WS, Oh RR, Park JY, Kim PJ, Shin MS, Lee JH, Kim HS, Lee SH, Kim SY, Park YG, An WG, Jang JJ, Yoo NJ, Lee JY: Nuclear localization of betacatenin is an important prognostic factor in hepatoblastoma. J Pathol 2001, 193:483-490

26. Malanchi I, Peinado H, Kassen D, Hussenet T, Metzger D, Chambon P, Huber M, Hohl D, Cano A, Birchmeier W, Huelsken J: Cutaneous cancer stem cell maintenance is dependent on beta-catenin signalling. Nature 2008, 452:650-653.

27. Reya T, Clevers H: Wnt signalling in stem cells and cancer. Nature 2005, 434:843-850.

28. Saltz LB, Douillard JY, Pirotta N, Alakl M, Gruia G, Awad L, Elfring GL, Locker PK, Miller LL: Irinotecan plus fluorouracil/leucovorin for metastatic colorectal cancer: a new survival standard. Oncologist 2001, 6:81-91.

29. de Gramont A, Figer A, Seymour M, Homerin M, Hmissi A, Cassidy J, Boni C, Cortes-Funes H, Cervantes A, Freyer G, Papamichael D, Le Bail N, Louvet C, Hendler D, de Braud F, Wilson C, Morvan F, Bonetti A: Leucovorin and fluorouracil with or without oxaliplatin as first-line treatment in advanced colorectal cancer. J Clin Oncol 2000, 18:2938-2947.

30. Berthold DR, Pond GR, Soban F, de Wit R, Eisenberger M, Tannock IF: Docetaxel plus prednisone or mitoxantrone plus prednisone for advanced prostate cancer: updated survival in the TAX 327 study. J Clin Oncol 2008, 26:242-245.

31. Vermorken JB, Remenar E, van Herpen C, Gorlia T, Mesia R, Degardin M, Stewart JS, Jelic S, Betka J, Preiss JH, van den Weyngaert D, Awada A, Cupissol D, Kienzer HR, Rey A, Desaunois I, Bernier J, Lefebvre JL: Cisplatin, fluorouracil, and docetaxel in unresectable head and neck cancer. N Engl J Med 2007, 357:1695-1704

32. Cao S, Durrani FA, Rustum YM: Selective modulation of the therapeutic efficacy of anticancer drugs by selenium containing compounds against human tumor xenografts. Clin Cancer Res 2004, 10:2561-2569.

33. Azrak RG, Frank CL, Ling X, Slocum HK, Li F, Foster BA, Rustum YM: The mechanism of methylselenocysteine and docetaxel synergistic activity in prostate cancer cells. Mol Cancer Ther 2006, 5:2540-2548.

34. Combs GF Jr, Gray WP: Chemopreventive agents: selenium. Pharmacol Ther 1998, 79:179-192.

35. Goldhaber SB: Trace element risk assessment: essentiality vs. toxicity. Regul Toxicol Pharmacol 2003, 38:232-242.

36. Thomson CD: Assessment of requirements for selenium and adequacy of selenium status: a review. Eur J Clin Nutr 2004, 58:391-402.

37. Schneider-Poetsch T, Ju J, Eyler DE, Dang Y, Bhat S, Merrick WC, Green R, Shen B, Liu JO: Inhibition of eukaryotic translation elongation by cycloheximide and lactimidomycin. Nat Chem Biol 2010, 6:209-217.

38. Stambolic V, Ruel L, Woodgett JR: Lithium inhibits glycogen synthase kinase-3 activity and mimics wingless signalling in intact cells. Curr Biol 1996, 6:1664-1668.

39. Zhang W, Yan S, Liu M, Zhang G, Yang S, He S, Bai J, Quan L, Zhu H, Dong $Y, X u N$ : $\beta$-catenin/TCF pathway plays a vital role in selenium induced-growth inhibition and apoptosis in esophageal squamous cell carcinoma (ESCC) cells. J canlet 2010, 296:113-122.

40. Chintala S, Toth K, Cao S, Durrani FA, Vaughan MM, Jensen RL, Rustum YM: Se-methylselenocysteine sensitize hypoxic tumor cells to irinotecan by targeting hypoxia-inducible factor 1alpha. Cancer Chemother Pharmacol 2010, 66:899-911.

41. Li Y, Wang Z, Kong D, Murthy S, Dou QP, Sheng S, Reddy GP, Sarkar FH: Regulation of FOXO3a/beta-catenin/GSK-3beta signaling by $3,3^{\prime}$ diindolylmethane contributes to inhibition of cell proliferation and induction of apoptosis in prostate cancer cells. J Biol Chem 2007, 282:21542-21550.

\section{doi:10.1186/1476-4598-9-310}

Cite this article as: Saifo et al.: Targeting the oncogenic protein betacatenin to enhance chemotherapy outcome against solid human cancers. Molecular Cancer 2010 9:310.

\section{Submit your next manuscript to BioMed Central and take full advantage of:}

- Convenient online submission

- Thorough peer review

- No space constraints or color figure charges

- Immediate publication on acceptance

- Inclusion in PubMed, CAS, Scopus and Google Scholar

- Research which is freely available for redistribution 